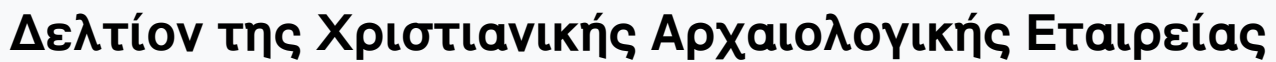

Tó 32 (2011)

$\Delta \varepsilon \lambda$ tíov XAE 32 (2011), Пعрíoঠos $\Delta^{\prime}$

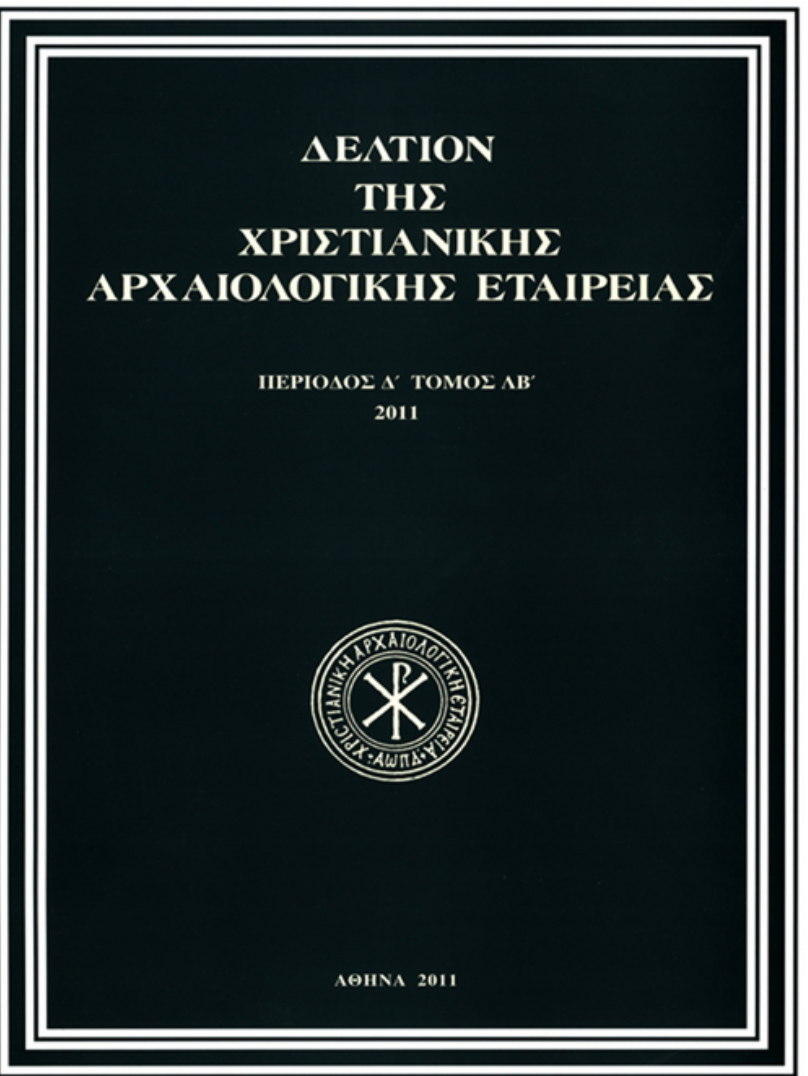

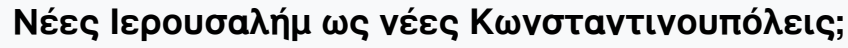

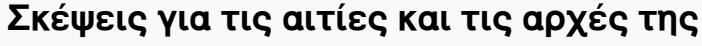

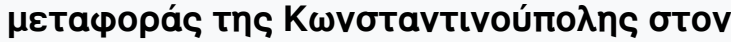

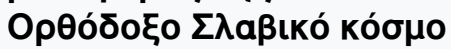

Jelena ERDELJAN

doi: $\underline{10.12681 / \text { dchae.682 }}$

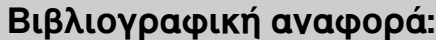

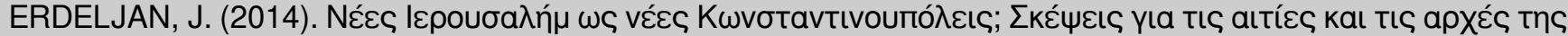

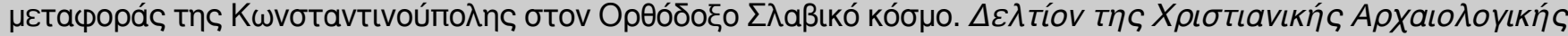
Eтaısías, 32, 11-18. https://doi.org/10.12681/dchae.682 


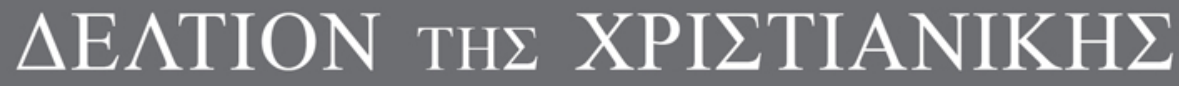 APXAIO $\Lambda$ OГIKH $\Sigma$ ETAIPEIA $\Sigma$}

New Jerusalem as New Constantinoples? Reflections on the reasons and principles of Translatio

Constantinopoleos in Slavia Orthodoxa

Jelena ERDELJAN

$\Delta \varepsilon \lambda \tau$ tíov XAE $32(2011) \bullet \Sigma \varepsilon \lambda .11-18$

A@HNA 2011 


\author{
Jelena Erdeljan
}

\title{
NEW JERUSALEMS AS NEW CONSTANTINOPLES? REFLECTIONS ON THE REASONS AND PRINCIPLES OF TRANSLATIO CONSTANTINOPOLEOS IN SLAVIA ORTHODOXA
}

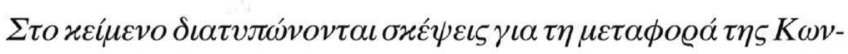

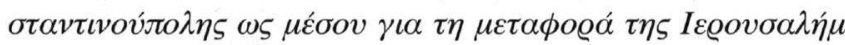

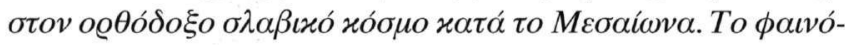

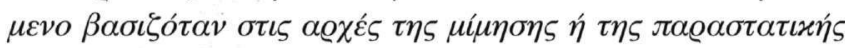

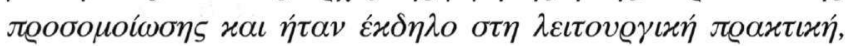

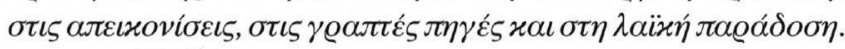

This text reflects on translatio Constantinopoleos as a means of translatio Hierosolymi in Slavia Orthodoxa in the Middle Ages. This phenomenon was based on the principles of mimesis or performative emulation and demonstrated in liturgical practice, visual culture, written sources and folklore.

\begin{abstract}
A of taxis, or world order as it had previously functioned for almost a millennium, hallmarks of Constantinopolitan identity as New Jerusalem, umbilicus mundi or o $\phi \theta \alpha \lambda \mu$ ó $\varsigma \tau\rceil$ oเxov $\mu \varepsilon^{\prime} \nu \varsigma^{1}$, were appropriated by capital cities of the Empire of Nicea, Despotate of Epirus and the Empire of Trebizond, states which appeared as the result of the fall and fragmentation of the Byzantine Empire. At roughly the same time, and following a mechanism structurally analogous to that of translatio Hierosolymi, other centers as well, namely those of the newly formed or restored states which were part of the broader framework of the Byzantine Commonwealth, like the
\end{abstract}

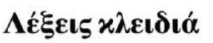

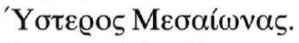

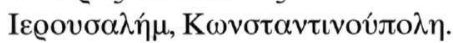

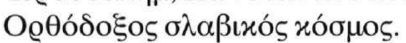

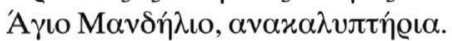

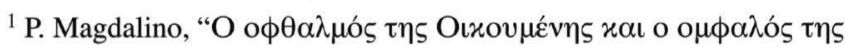

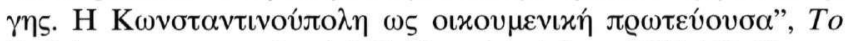

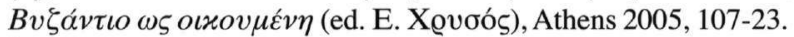

${ }^{2} \mathrm{~A}$. Eastmond, "Byzantine Identity and Relics of the True Cross in the Thirteenth Century", Восточнохристианские реликвии (ed. A. М. Лидов), Moscow 2003, 205-15 (hereafter: "Вyzantine Identity"). Д. Поповић, "Реликвије и политика: српски приступ”, Под окриљем светости. Култ светих владара и реликвија у средњовековној Србији, Beograd 2006, 253-70. See also J. Erdeljan, “Appropriation of
}

Serbian state of the Nemanides, the restored or Second Bulgarian Empire and the Muscovite state liberated of the dominance of the Golden Horde, embarked on the course of constructing their particular selves on the basis of appropriating and (re)interpreting the crux Constantinopolitan identity $^{2}$. At the same time, given the contemporary currents of political history, key elements of Constantinopolitan identity as New Jerusalem were also utilized and adapted to bolster the legitimacy and strengthen the status of already existing royal i.e. dynastic and state identities, those of Louis IX and the Venetian doges, and to transform, fittingly, Paris and Venice into universal centers of power ${ }^{3}$. On the other hand,

\footnotetext{
Keywords

Late Middle Ages.

Jerusalem, Constantinople.

Slavia Orthodoxa.

Mandylion, anakalypteria.
}

Constantinopolitan Identity in the Late Middle Ages: the Case of Trnovo and Belgrade", Proceedings of the 21st International Congress of Byzantine Studies, vol. III, Abstracts of Communications (eds F. K. Haarer, E. Jeffreys), London 2006, 67-68. Ead., "New Jerusalems in the Balkans: Translation of Sacred Space in the Local Context", New Jerusalems. The Translation of Sacred Spaces in Christian Culture (ed. A. Lidov), Moscow 2009, 458-74.

${ }^{3}$ B. Flusin, "Les reliques de la Sainte-Chapelle et leur passé impérial à Constantinople", Le tresor de la Sainte-Chapelle, Paris 2001, 20-31. J. 
notwithstanding the tendency to underscore the continuity of authority expressed through numerous aspects of the reign of Frankish emperors, the Latin Kingom, the sole state established after 1204 which had literally and geographically incorporated Constantinople, did not, apparently, assign much importance to the historical, symbolic and ideological dimension of the ancient capital of the Byzantine Empire ${ }^{4}$.

In the broadest sense, the mentioned process of constructing New Jerusalems as New Constantinoples can be observed as an element of the process of moving, redistributing and multiplying the number of centers of the medieval world, being, at once, both the cause and the effect of the process of particularization of late medieval society i.e. of inidividualization and privatization of sacrality and symbols which had previously been the prerogative of one single center ${ }^{5}$. An entirely specific issue in its own right is the question of the meaning and implications of appropriation as such in a given historical context. Having in mind the origins of this term in the discourse of colonialism, appropriation as a form of intercultural exchange can resound with implicitly negative connotation. However, during the high and late Middle Ages, and particularly in the wake of events of 1204, it was precisely this re-assignment, transmission and re-reading of elements of the original or prototype, in this case of Constantinopolitan identity, that conferred a higher sense of meaning and an entirely special raison d'etre to Arta, Nicea and Trebizond or Paris and Venice, to name only the most prominent examples of this phenomenon and the most directly recognizable legatees of Constantinople and the Empire of the Romaioi after the Fourth Crusade. After all, the principles and aesthetics of performative emulation or mimesis are deeply imbedded in the fabric of the ancient, time sustained system of values of the Byzantines, based as much on Roman attitude toward decorum as on Christian ideas of the eikon, the image and the archetype ${ }^{6}$. Constantinople itself as the ultimate example of the spatial icon of the ideal city ${ }^{7}$ was regarded as a prototype to be emulated, transferred or, more precisely, imprinted on other spaces which thus strove to become its iconic likeness - both in the general idea of God-chosen and God-protected place, i.e. New Jerusalem, the core of its identity as universal capital, and/or in the individual elements, devotional and visual, upon which such an identity was constructed.

In that sense and for the purpose of realizing such a goal, this sort of appropriation or re-investment relied, among other means, on a new utilization of definitive Constantinopolitan relics, above all those of the Passion of the Lord. Outside Constantinople, in accordance with medieval principles of emulation of the archetype, they were used to construct the identities and define the positions in the family of Christian nations of those states which, for different reasons and by different means, claimed the right to establish themselves as heirs of Byzantium ${ }^{8}$.

The Holy Cross was, beyond any doubt, the principal instrument in that endeavor. Its direct imperial connotations granted legitimacy of rule to those who regarded themselves as legatees of state and polity of the Empire of the Romaioi. Examples of circulation and new exploitation of the relic of the True Cross and, in certain cases, of other Passion relics as well, which played a prominent role in the process of fragmentation of Byzantine identity after 1204, are found, for example, in Trebizond (under Manuel I Great Komnenos), Nicea (under John III Vatatzes) ${ }^{9}$, Serbia (under the first Nemanides) ${ }^{10}$, Venice ${ }^{11}$ and, finally, within what was essentially a most comprehensive program of translatio Constantinopoleos, Paris in the days of Louis $\mathrm{IX}^{12}$. Because it is well documented and studied, and thus easily identifiable, this phenomenon appears, at first glance, to be the most
Durand, "Les reliques et reliquaires byzantins acquis par saint Louis", ibid., 52-54. D. Rosand, Myths of Venice. The Figuration of a State, University of North Carolina Press 2001. France and the Holy Land: Frankish Culture at the End of the Crusades (eds D. H. Weiss, L. Mahoney), Johns Hopkins University Press 2004.

${ }^{4}$ D. Jacoby, "The Urban Evolution of Latin Constantinople (1204 1261)", Byzantine Constantinople: Monuments, Topography and Everyday Life (ed. N. Necipoğlu), Leiden 2001, 277-97, esp. 297.

${ }^{5}$ One view of this process is expounded in S. C. Akbari, "From Due East to Due North: Orientalism and Orientation", The Postcolonial Middle Ages (ed. J. J. Cohen), Palgrave and Macmillan 2001, 19-35.

${ }^{6}$ B. Pentcheva, "The Performative Icon”, ArtB 88, 4 (2006), 631-55, esp. 635.

${ }^{7}$ A. Lidov, "The Flying Hodegetria. The Miraculous Icon as Bearer of Sacred Space", The Miraculous Image in the Late Middle Ages and
Renaissance, Papers from a Conference held at the Academia di Danimarca in Collaboration with the Bibliotheca Hertziana, MaxPlanck-Institut für Kunstgeschichte (eds E. Thun $\varnothing$, G. Wolf), Rome 2005, 273-304.

${ }^{8}$ Eastmond, "Byzantine Identity", passim, including examples from Serbia, Bulgaria, Georgia, and Armenia, as well as France. Поповић, "Sacrae reliquiae Спасове цркве у Жичи", Под окриљем светости, (n. 2), 207-32. Ead., "Реликвије и политика", ibid., passim, with examples not only from medieval Serbia but also from Bulgaria, Russia, Georgia, Armenia, France, Hungary, Poland, Moravia and their role in translatio Hierosolymi for the purpose of translatio imperii.

${ }^{9}$ Eastmond, "Byzantine identity", 211-12.

${ }^{10}$ Поповић, "Реликвије и политика", op.cit. (n. 2), 254-59.

${ }^{11}$ Rosand, Myths of Venice (n. 3) 13-18.

${ }^{12}$ Durand, "Les reliques et reliquaires", op.cit. (n. 3), 52. 
clearly defined and convincing mode of appropriating Constantinopolitan identity - overshadowing others which, although not as immediately decipherable, are nonetheless equally significant in realizing the same objective. These are elements of liturgical practice, primarily urban litanies, as well as aspects of the more fluid and ever changeable sphere of visual culture.

The case of the Despotate of Epirus and its capital Arta bears witness to the modes and implications of transferring Constantinopolitan matrices for the purpose of constituting an idiosyncratic identity of a New Jerusalem fashioned after the model of the capital of the Empire. Although the sacral topography of the city of Arta has yet to be studied in greater detail and examined from the point of view of the above stated phenomenon, it is possible to conclude, on the basis of preserved monuments and pertaining visual culture, that at least two key Constantinopolitan cults had been transferred to the capital of the Epirote state. Whatsmore, these were cults which conferred most directly the aura of God-chosen and God-protected status to the new capital and, as in Constantinople, consigned both the city and the ruling dynasty of Douka Komnenos to the protection of the Mother of God $^{13}$. The mausoleum of Epirote rulers is dedicated to the Virgin Blachernitissa and the same church preserves a fresco representing a liturgical procession with the icon of the Virgin Hodegetria ${ }^{14}$. Regardless of whether this is an image of the trade mark Constantinopolitan urban rite or a local procession with a copy of the miracle working icon of the holy protectress of the Byzantine state and its center, it is clear that reference to the palladium of the Empire played an exceptionally prominent, key role in the process of constructing the identity of the new capital as a new Constantinople, i.e. a New Jerusalem.

Along with that, the main church of Arta dedicated to the Virgin Parigoritissa ${ }^{15}$ could be seen as a sort of visualization of sublimation of time and space, a principle realized ultimately in the Megali Ecclesia of Constantinople, underscored by a pointed and highly visible use of spoliae. One could also say that the Parigoritissa emulated also the visual effect of the hovering dome, a trade-mark element of visual rhetoric of sanctity of Hagia Sophia - although, of course, in a strictly architectonic and structural sense the dome and pertaining supporting

\footnotetext{
${ }^{13}$ N. Baynes, "The Supernatural Defenders of Constantinople", AnBoll LXVII (1949), 165-177. C. Mango, "Constantinople as Theotokoupolis", Mother of God. Representations of the Virgin in Byzantine Art (ed. M. Vassilaki), Milano 2000, 17-25. B. Pentcheva, Icons and Power. The Mother of God in Byzantium, The Penns. State University Press 2006

${ }^{14}$ Lidov, "The Flying Hodegetria”, op.cit. (n. 7), 299. On the churches
}

elements of the Parigoritissa bear no direct links to those of Hagia Sophia of Constantinople nor, for that matter, to those of any other Byzantine church. The overall effect, however, just as in Hagia Sophia, is directed at experiencing heaven on earth, the connection between the celestial and the terrestrial sphere. Observed from that point, the overall image of the Parigoritissa as a combination of the cube and the hemisphere, not only conceptually but formally, too, could be interpreted as an image of the cosmos, of an ideal connection of heaven and earth, as determined and visualized in the writings of Cosmas Indikopleustes and, of course, articulated in the architecture of Hagia Sophia of Constantinople. At the same time, the already registered similarities between the architecture of the Parigoritissa and residential court architecture ${ }^{16}$ can gain a higher level of meaning precisely because the church should represent the ideal, heavenly residence or court on earth. The plan and structure of the Parigoritissa may, thus, also be interpreted as a sort of (re)interpretation of Justinianic models, i.e. of those ideals produced by the Golden Age which when incorporated as constitutive elements of the ideal past into the present present a matrix of the ultimate and perfect, eschatological future.

While the above examples from Epiros are highly symbolic, the Trebizond centered Empire of the Great Komnenoi probably went (literally) farthest in transferring Constantinopolitan visual identity and, furthermore, in a manner which also bore connotations of translatio reliquiarum. In the endeavor of raising the main church of the capital city of Trebizond, the royal foundation of St. Sophia, pillars were transported from the old capital on the Bosphoros and then incorporated into its architectural structure as spoliae ${ }^{17}$.

The practice and instruments of defining (other) points across the Christian oikoumene as New Jerusalems by means of appropriation of Constantinopolitan warrants of salvation as well as of elements of the sacred spaces of the capital of the Byzantine Empire, including both their overall visual identity as well as their peculiar iconographic and hierotopic solutions, are probably best exemplified by cases of transferring trade-mark constituent elements of the church of the Virgin of Pharos. Because it was universally perceived as the ultimate sacred focus of the universal Empire, the archetype new Sepulchre of the Lord,

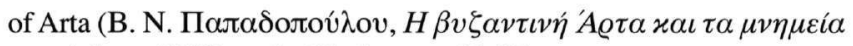
$\tau \eta \zeta$, Athens 2002) on the Blachernae, 69-87.

${ }^{15}$ Ibid., 131-159.

${ }^{16}$ Mango, Byzantine Architecture, Milan 1978, 146-148.

${ }^{17}$ A. Eastmond, Art and Identity in Thirteenth-Century Byzantium, Hagia Sophia and the Empire of Trebizond, Ashgate 2004, 41-46, esp. 44. 
new Holy Land, the ultimate icon of Jerusalem, its reliquary as well as visual identity was regarded as a model of realization and visualization of the idea of Jerusalem in the Christian world, both East and West. From the Middle Byzantine period to the end of the Middle Ages the mystical ambience of the Virgin of Pharos functioned, even after its material destruction, as the achetype-icon of the Holy Land and the Holy Sepulchre, as a proper substitute of the Jerusalem prototype. Examples of emulation of that model are most easily detected when they rely on a transfer of the staple cults and relics kept and venerated in this imperial chapel. In certain cases, however, emulation is based on the transfer or adoption of elements of the visual identity of this holy place, its program of decoration as well as its individual hierotopic units and installations ${ }^{18}$.

In a certain manner, the most comprehensive example of mimesis of the Virgin of Pharos for the purpose of translatio Hierosolymi was executed in Paris, in the Sainte-Chapelle of Louis IX. This was achieved not only by the presence therein of practically the entire reliquary program of the Constantinopolitan imperial church-reliquary but also, and in equal measure, by the construction of a peculiar visual identity of the church-reliquary of the French monarchy which, although conveyed in the idiom of XIII century Gothic, relied on key categories of visual identity of the Virigin of Pharos - luminescence and transparency ${ }^{19}$. In a visually different manner and determined by different historical circumstances, the Limburg staurotheke also repeats the reliquary contents of the Virgin of Pharos as a matrix of Holy Land sacred topography ${ }^{20}$. The marked presence of the Passion relics, once kept in the Pharos church, in iconographic formulae of scenes from the cycle of the Passion of Christ in Middle and Late Byzantine art, particularly in representations of the Threnos, is also a mode of appropriation and evidence of the influence exerted by the model set up by the Virgin of Pharos. An even more direct way of inclusion of the Pharos archetype of sacred space and program in the sacred spaces of numerous churches throughout the Christian world, achieving thus symbolic union not only with the mentioned Constantinopolitan

\footnotetext{
${ }^{18}$ А. М. Лидов, “Церковь Богоматери Фаросской. Императорский храм-реликварий как константинопольский Гроб Господень”, Византийский мир: искусство Константинополя и националные традиции, К 2000-летию христианства, Москва 2005, 79-108, in particular 86.

${ }^{19}$ Le tresor de la Sainte-Chapelle (n. 3) passim; А. М. Лидов, “Церковь Богоматери Фаросской”, ор.cit., 89-90.

${ }^{20}$ Ibid., 82 .

${ }^{21}$ Ibid., 94, 96, with examples of the Threnos in Nerezi and the Virgin Peribleptos in Ohrid as well as the Mandylion and Keramion from
}

sacred space of the Pharos but, through it, also with the Jerusalem archetype proper on which it was modeled, is the positioning of fresco representations of the Mandylion and Keramion on arches supporting the domes of Middle and Late Byzantine churches - the very locations the actual relics originally occupied and at which they were displayed in the space of the Pharos chapel ${ }^{21}$. The same principle applies also to certain cases of representing the Virgin Eikokeira, the principal icon of the imperial churchreliquary of Constantinople ${ }^{22}$.

An entirely specific example of the way the appropriation of the various elements of identity of the sacred space of the Pharos chapel, including visual, was employed as a means of translatio Hierosolymi, because of the ultimate fusion of Jerusalem and Constantinople it implied, is the two sided icon of the Novgorod Mandylion with a representation of the acheiropoietos image on one side and Passion relics adored by two angels on the other. Not only does this icon substantiate the presence of Pharos chapel relics and underline the historical and symbolic aspects of the archetype, it also emphasizes the idea of the direct connection between two sacred places. It is a visualization of the concept of translating Jerusalem to Constantinople through the act of translation of relics (Passion relics) and creation of a space marked by shekinah, the presence of the Lord (manifested in the Mandylion). Moreover, being an icon of the sacred space of the Pharos chapel itself, it also underpins the way in which the appropriation of the ultimate Constantinopolitan model and substitute of (New) Jerusalem, in synergy with its performative presence through liturgy, granted to the space to which it was introduced the status of God-protected and God-chosen place - equal in that respect to the status of Jerusalem, Edessa and Constantinople ${ }^{23}$. As opposed to the other major Jerusalem acheiropoietos and ex contactu relic of Christ, the imprint of his feet on Mount of Olives on the spot of the Ascension, the Mandylion, with its history, is itself proof of translation of sanctity, of transfer of the presence of the power of the Lord ${ }^{24}$. That proof is offered not only by the iconographic contents of

\footnotetext{
Miroz monastery of Pskov. See also id., "Мандилион и Керамион как образ-архетип сакрального пространства", in Восточнохристианские реликвии (n. 2), 249-80.

${ }^{22}$ Id., “Церковь Богоматери Фаросской”, op.cit. (n. 18), 99-100, with an example from the Panagia tou Arakou in Cyprus.

${ }^{23}$ Ibid., 94.

${ }^{24}$ G. Wolf, "The Holy Face and the Holy Feet: Preliminary Reflections before the Novgorod Mandylion", Восточнохристианские реликвии (n. 2), 281-89, esp. 282-83.
} 
the icon but also by its visual characteristics, in particular the color combination of white and gold which restates the dominant trait of visual identity of the Pharos chapel and, at the same time, of the actual fabric of the cloth in the gold reliquary in which it was kept. Because the ideal of Jerusalem and the reality of Constantinople are united in such a sophisticated manner, by iconographic and visual means, the icon of the Novgorod Mandylion can also be regarded as an icon of translatio Hierosolymi ${ }^{25}$.

The study of the various aspects of this icon introduces us also to the question of the entirely specific bond with Constantinople nurtured in Slavia Orthodoxa. This relationship is expressed most convincingly through historical formulae which, on the one had, determine the nature of the universal capital and, on the other, functioned also as attributes of the individual capitals of the different states of Slavia Orthodoxa. By giving Constantinople the name Tsarigrad (Imperial City), the Slavs mythologized the capital of the Byzantine Empire and defined it as the seat of imperial, God given power and force $^{26}$. As a result, from Simeon's First Bulgarian Empire to the Muscovite state of Ivan IV the Terrible, appropriating Constantinopolitan identity was, logically, an integral part of constructing the idiosyncratic identities of states of Slavia Orthodoxa. In Bulgarian and Russian chronicles and other written sources this is primarily accomplished by assigning the historical formula of New Constantinople to a capital city of the Slavic state in question, a formula defining the nature, i.e. the origins of power, of the capital and the state, one which belongs to a line of similar formulas including also New Rome, New Kiev or New Babylon ${ }^{27}$. To an even greater extent, this code is present in the oral tradition, in folklore legends and epics. In both the written sources and folklore, the act of being identified with Constantinople is equal to that of establishing a bond with the archetype ${ }^{28}$.

Russian folklore is replete with examples of replacing names of lesser symbolic significance with those of higher meaning. The basic procedure is a simple change by which, for example, in the Russian epic The Rage of Ivan the Terrible Moscow is simply called Tsarigrad (Constantinople). Other numerous examples are found in folk songs where, for instance, any of the given larger Russian rivers - the Don, the
Dnjepar or the Moskva - are all called Dunay (the Danube) because it is the Danube which embodies the very idea of the river as such and because any local river is seen as a likeness of the archetype ${ }^{29}$. In other cases, the bond between a given phenomenon and its archetype is expressed as a sort of genetic or hereditary relationship. Thus, for example, in "Golubinnaya kniga", one of the most exalted Russian spiritual folk ballads, we find mention of "...the whale fish mother of all fish... Jordan river mother of all rivers... Jerusalem city father of all cities" 30 . This example of "family ties", so to say, testifies of the frequent practice of establishing links not only between archetypes and their realizations but, above all, between the two archetypal, mythologized centers of the Oikoumene, Jerusalem and Constantinople, which, in a great number of cases registered in Slavic, and in particular Bulgarian and Russian folklore, function as interchangeable substitutes. For example, in the 17th century Russian text of The History of the City of Jerusalem, closely connected to folklore tradition and the "Golubinnaya kniga" in particular, the very idea of Jerusalem already includes the concept of Constantinople while the Muscovite Empire appears as a reflection of that twofold and, at once, quintessentially integrated archetype. Namely, when speaking of the appearance of Jerusalem among the Russians, this text speaks of it as "the city of the origins" which shall "house the cathedral and apostolic church of Sophia Wisdom of the Lord", indicating not only the notion that the Great Church of Constantinople was regarded in Eastern Christianity as one of the most relevant examples of translatio Hierosolymi and a sacral substitute and kernel of the capital of the Byzantine Empire, but also the essential unity of Constantinople and Jerusalem ${ }^{31}$.

The highly symbolic substance of Constantinople in South Slavic folklore, especially that related to matrimonial rites, and in particular following the events of 1453, is often expressed through the notion of Tsarigrad as the city of nuptials. In a number of tales and ballads it is there that the bride or bridegroom awaits, going to Tsarigrad implies entering into matrimony, while the city itself appears as the king's beloved, the adored capital-bride of the king. Other symbolic actions implying the act of unification with the archetype and described in folklore include also the act of taking of or laying

\footnotetext{
${ }^{25}$ Ibid., 283-284, 287.

26 Ф. К. Бадаланова-Покровская, М. Б. Плюханова, “Средневековые исторические формулы Москва/Тырново - Новый Царьград”, Текст - Культура - Семиотика нарратива, Труды по знаковым системам ХХIII, Tapty 1989, 80-94, esp. 84.
}

\footnotetext{
${ }^{27}$ Ibid., 82 .

${ }^{28}$ Loc.cit.

${ }^{29}$ Loc.cit.

${ }^{30}$ Ibid., 82-83.

${ }^{31}$ Ibid., 83.
} 
siege to a city as well as the act of rising to the status of empire $^{32}$. The symbolism of the folklore motif of matrimony corresponds at once with the ancient topos of anakalypteria which had, from the beginning, been incorporated into Byzantine Christian tradition. The motif of lifting of the bridal veil before the groom, originating from the matrimonial ritual of Antiquity, was since ancient times imbued with the symbolism of civilization, of the moment at which man is elevated to homo humanus and chaos is transformed into cosmic order and universal taxis $^{33}$.

In the context of the subject of this paper, it is particularly significant to mention that it was precisely the motif of anakalypteria that Constantine Porphyrogenitos relies on in his description of the transfer of the Mandylion from Edessa to Constantinople ${ }^{34}$ for the purpose of conveying the very essence of the most dramatic moment in the history of this acheiropoietos image - Abgar's encounter with the apostle Thaddeus from whose face his stripped the holy cloth and, covering it with kisses, pressed it against his own face and body ${ }^{35}$. Episodes of this, we can freely say, ancient drama on the creation and transfer of the Mandylion from Jerusalem to Edessa are visualized most comprehensively on the well known revetted silver-gilt frame (dating from around the year 1300) of the icon of the Mandylion from the Genovese church of San Bartolomeo degli Armeni ${ }^{36}$. Because Edessa was considered to be the first Christian state, for the role it played in the history of the Mandylion, in the text composed by Porphyrogenitos the motif of anakalypteria bore, in the broadest sense, the symbolism of unity of state and Christian faith, an act of civilization per se, while, in the more narrow sense, it implied equating Constantinople with Edessa and, finally, in a personal context, it offered confirmation of legitimacy of his own reign as the sole ruler of the Byzantine
Empire. Porphyrogenitos's personal connection to the Mandylion, its transfer to Constantinople and the privilege of having the vision of the holy image as a vexillum of his triumph over his rivals, the sons of Roman I Lakapenos, played a key role in realizing his imperial position. It is, therefore, possible that the image of Abgar from the famous 10th century icon from the monastery of St. Catherine on the Sinai is actually a portrait of this emperor of the Macedonian dynasty who saw himself as the new Abgar and his capital as the new Edessa, i.e. New Jerusalem ${ }^{37}$.

Just as the union of the old and the new Abgar with the Mandylion definied Edessa and Constantinople as places transformed into God-chosen, "perfect" places in history, so was the appropriation of Constantinopolitan identity in Slavia Orthodoxa regarded as a definitive act of civilization with the same (anticipated) result. The means, tools, contexts and specific results of the various endeavours of realizing this goal in Orthodox Slavic states during the Middle Ages differ from case to case in both ideas and visuality or culture in general. On the other hand, research of historical formulae employed in Bulgarian, Serbian and Russian texts, in particular those of the late Middle Ages, has long since shown how their state rhetoric shared common roots and revealed the ways in which, for example, formulae created by the Trnovo school were introduced to Russia by metropolitan Cyprian and his circle ${ }^{38}$. Those paths were not always direct and it was precisely the specific approaches, strategies of emulation of the archetype adopted by each individual milieu, their own creative interpretations and different receptions of the universal matrix, of the essentially one and the same Jerusalem and Constantinople, that produced the complex and distinctive identities of capitals of the different Orthodox Slavic states in the Middle Ages.

\footnotetext{
${ }^{32}$ Ibid., 90.

${ }^{33}$ On the meaning of this motif and its use in the Byzantine world see G. A. Peers, "Masks, Marriage and the Byzantine Mandylion: Classical Inversions in the Tenth Century. Narratio de translatione Constantinopolim imaginis Edessenae", Intermédialités. Histoire et théorie des arts, des letters et des techniques 8 (2006), 13-30, esp. 24-25.

34 C. Porphyrogennetos, Narratio de translatione Constantinopolim imaginis Edessenae, $P G, 113$, col. 421-54.
}

\footnotetext{
${ }^{35}$ Peers, op.cit., 16-22.

${ }^{36}$ Id., Sacred Shock. Framing Visual Experience in Byzantium, Penns. State University Press 2004, 178.

${ }^{37}$ Id., "Marriage and the Byzantine Mandylion", op.cit. (n. 33), 16, 2930.

38 D. Strémooukhoff, "Moscow the Third Rome: Sources of the Doctrine”, Speculum XXVIII, 1 (1953), 84-101.
} 
Jelena Erdeljan

\section{NEE $\Sigma$ IEPOY $\Sigma$ A $\Lambda$ HM $\Omega \Sigma$ NEE $\Sigma$ K $\Omega$ N $\Sigma$ TANTINOYMO $\Lambda$ EI $\Sigma$;

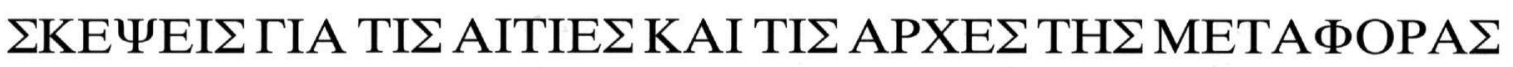

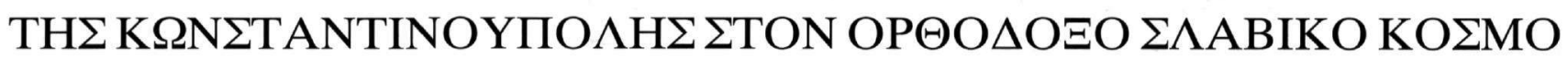

M

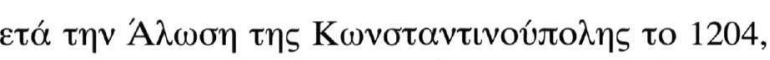

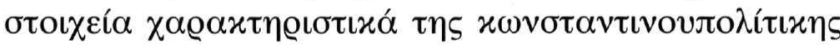

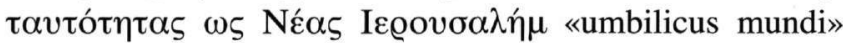

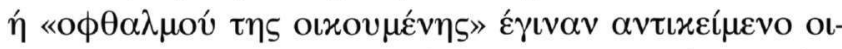

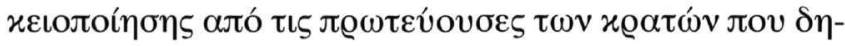

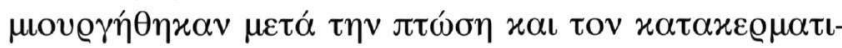

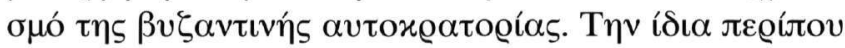

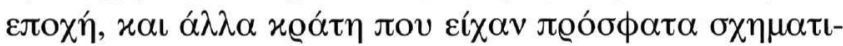

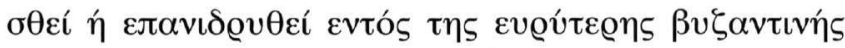

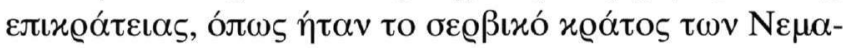

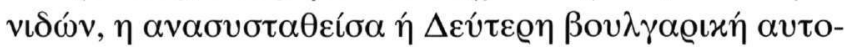

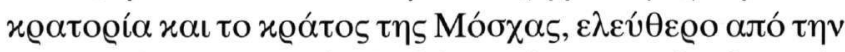

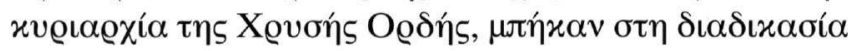

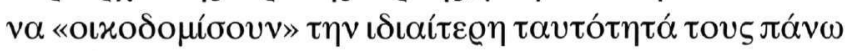

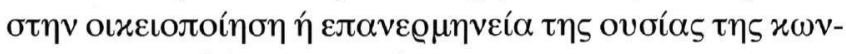

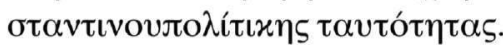

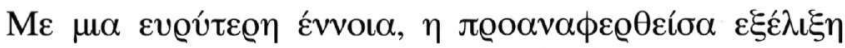

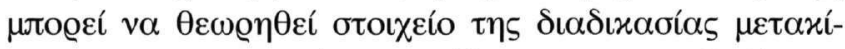

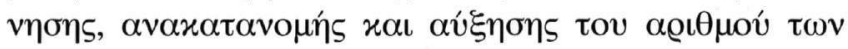

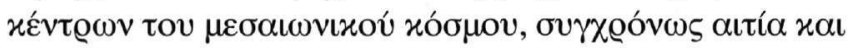

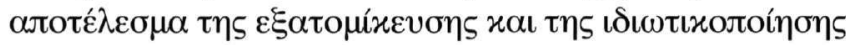

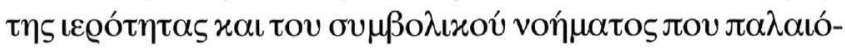

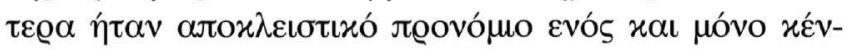

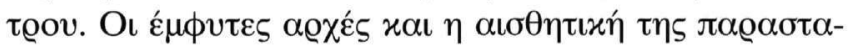

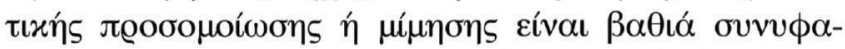

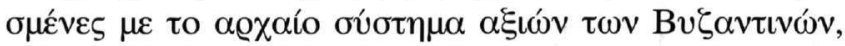

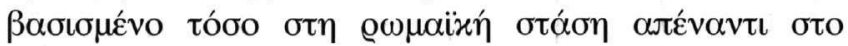

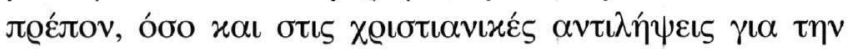

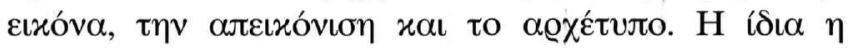

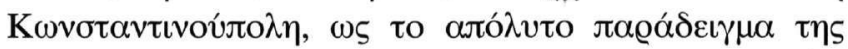

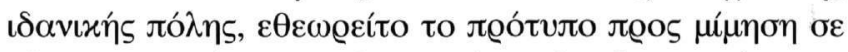

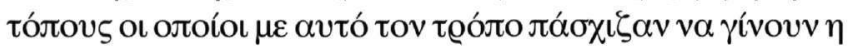

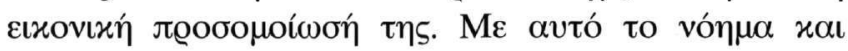

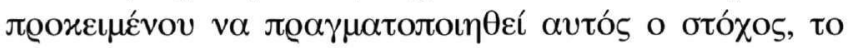

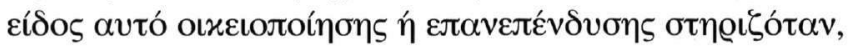

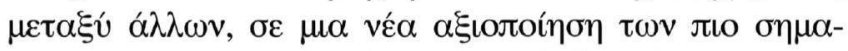

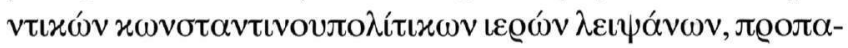

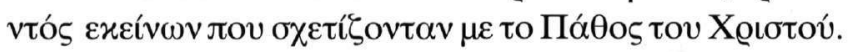

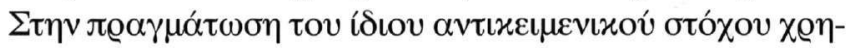

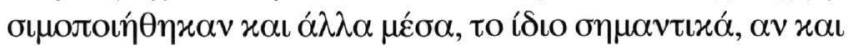

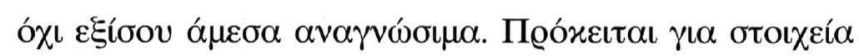

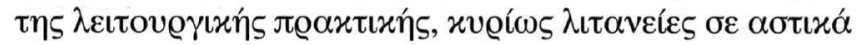

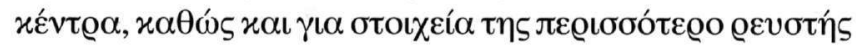

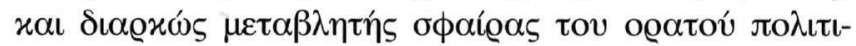

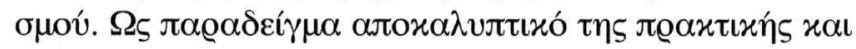

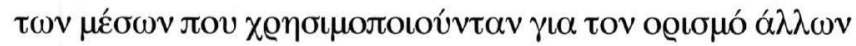

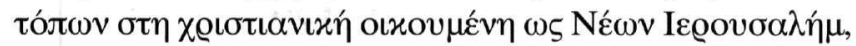

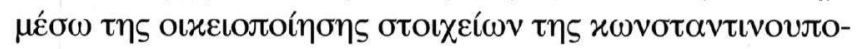

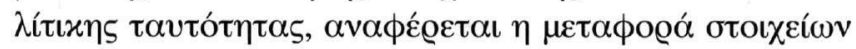

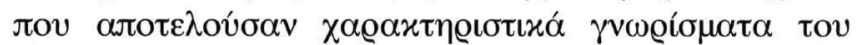

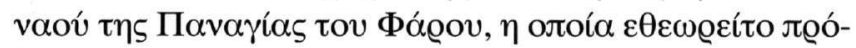

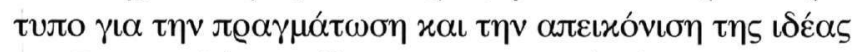

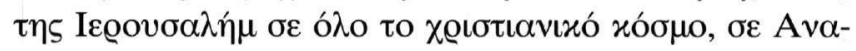

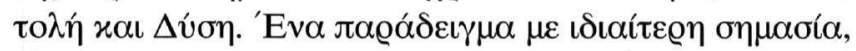

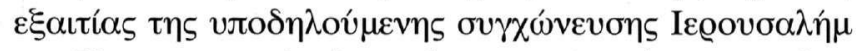

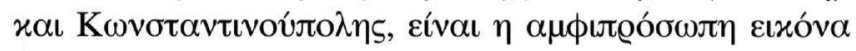

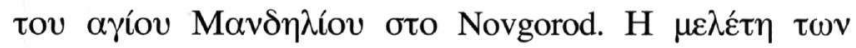

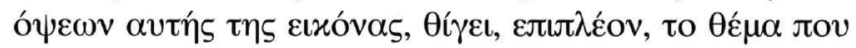

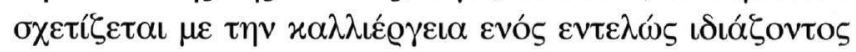

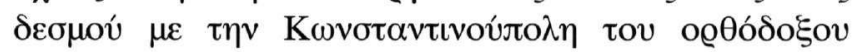

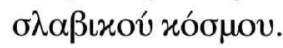

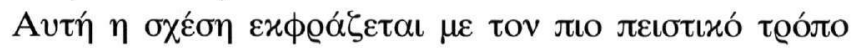

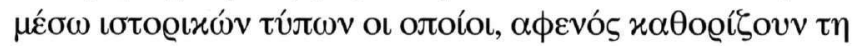

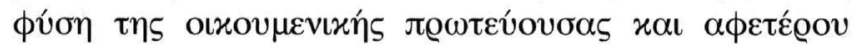

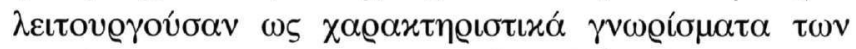

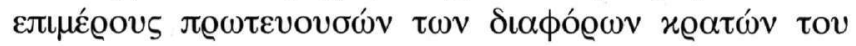

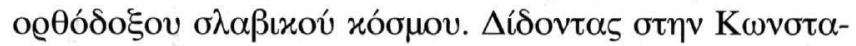

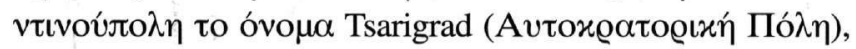

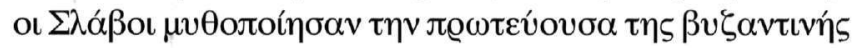

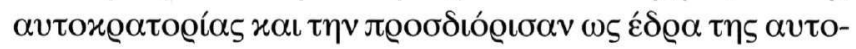

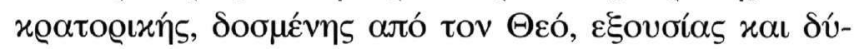

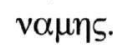

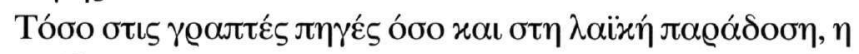

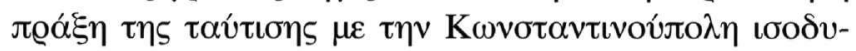

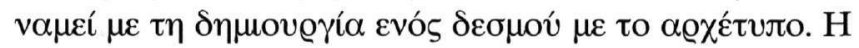

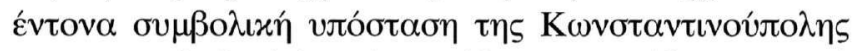

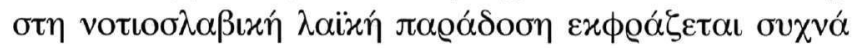

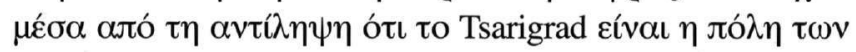

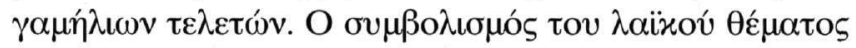

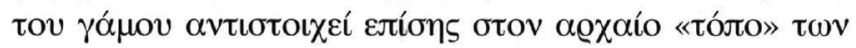




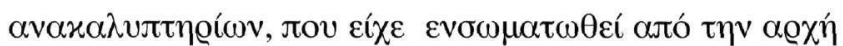

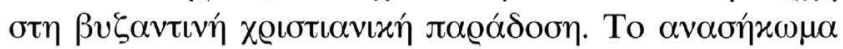

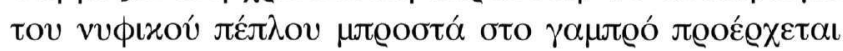

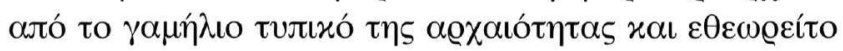

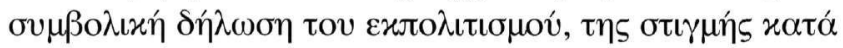

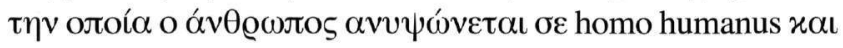

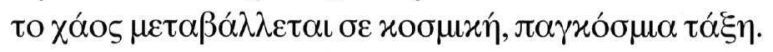

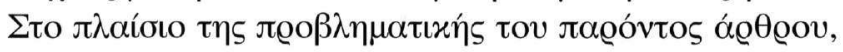

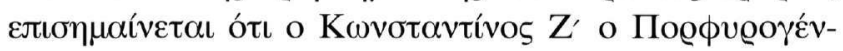

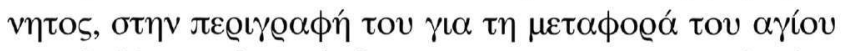

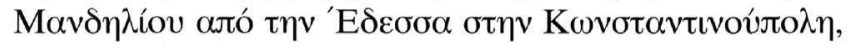

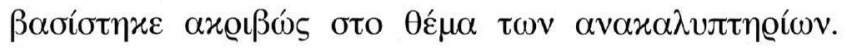

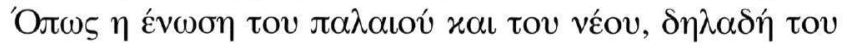

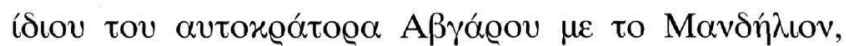

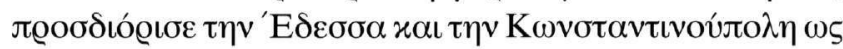

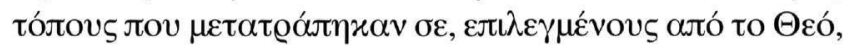

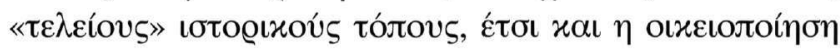

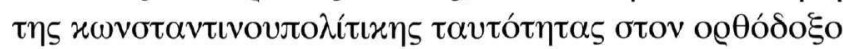

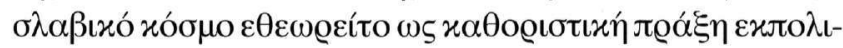

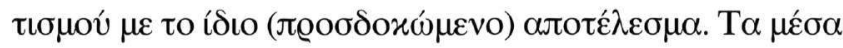

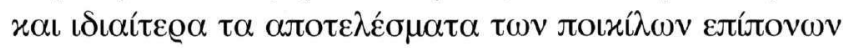

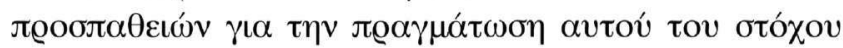

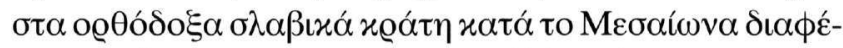

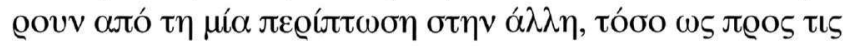

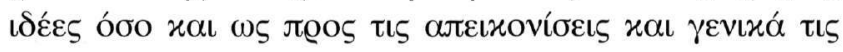

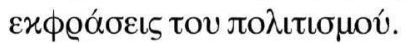

